\title{
Same same but different: managerial influences on organisational performance in foundations and associations
}

\author{
Georg von Schnurbein
}

Published online: 10 September 2013

(C) Springer-Verlag Berlin Heidelberg 2013

\begin{abstract}
In the last few years the management orientation of nonprofit organisation (NPOs) has been gaining importance. Management is said to have made the organisation of NPOs more effective and efficient. However, the influence of the institutional settings is often neglected in nonprofit management literature. By using a quantitative empirical approach this study investigates the influence of the legal type of Swiss nonprofits on the relationship between management dimensions and organisational performance. The research findings reveal significant differences in the management of foundations and associations. In particular, foundations have a competitive advantage in terms of innovation and market orientation. Whereas associations profit from investing in governance issues.
\end{abstract}

Keywords Nonprofit organisation · Management · Performance · Innovation · Isomorphism

JEL classification $\quad$ D64 $\cdot$ L3 $1 \cdot$ L33

\section{Introduction}

Nonprofit organisations (NPOs) are regarded as economic entities that differ from other private economic units specifically in their voluntary commitment and absence of profit incentive (Anheier and Toepler 2005). These differences account for the view of NPOs as a third subdivision in addition to the state and market sectors, a view that is supported chiefly by the theories of the failures of the state and the market as important major factors for the existence of NPOs. This demarcation is

G. von Schnurbein $(\bowtie)$

Centre for Philanthropy Studies (CEPS), Universität Basel, Peter Merian-Weg 6,

4002 Basel, Switzerland

e-mail: georg.vonschnurbein@unibas.ch 
also maintained in business management theory where a consumer economics NPO is distinguished from a commercial company. Although the heterogeneity of NPOs is repeatedly emphasised, distinctions in NPO managements are scarcely made in describing and analysing them (Badelt et al. 2007; Schwarz 2005). The only difference in NPO types taken into consideration in wide sections of the existing management literature occurs in accordance with the primary beneficiaries. Schwarz et al. (2009) speak of mutual benefit NPOs and third party NPOs in order to distinguish among NPOs whose benefits accrue either primarily to their own members (e.g., trade associations) or to third parties (e.g., care institutions). (Seufert (1999) designates these NPO types as self-help and outside-help NPOs, respectively). In the organisation of management this distinction becomes noticeable chiefly in the co-determination of the beneficiaries and the financing structure. In mutual benefit NPOs the identity principle of the members and customers is in force (Schwarz 1984), while in third-power NPOs members or donors do not have to be simultaneously beneficiaries. This difference permits one to conclude that different procedures in the decision-making process in the organisation are operative. As far as financing is concerned, fund raising has a higher significance for the third-power NPOs, since the beneficiaries themselves cannot pay for the benefits (Purtschert 2005).

Although the typology of the NPO modelled on legal forms is taken into consideration in management theory, nevertheless it occupies a subsidiary position. Schwarz (2005) argues: 'The management of a museum, a hospital ... draws from a general management theory for/from foundations (whatever their contents might be) no additional knowledge that is important for their service production' (p. 363).

Changes in the NPO sector in the last few years, however, provide an occasion to question, at least in part, the neglect of the legal form in the management analysis of the NPOs. Of the three significant NPO legal forms, ${ }^{1}$ cooperatives, associations and foundations, associations are considered the most common and most widespread legal form. This recognition derives chiefly from its legally simple start-up procedures and versatile applicability (Nowotny and Fida 2007). Associations are found in every area of public and private life, from sports associations to trade associations to hospitals (Badelt et al. 2007). In contrast, the interest in foundations has increased only in the recent past and their applicability has become more diversified. Since the reunification of Germany in 1990 some $70 \%$ of the existing incorporated and nonprofit foundations in Germany have been established. In addition, in other countries the foundation sector has in the past 20 years developed at a higher than average rate. Thus in Switzerland $57 \%$ of the nonprofit foundations originated after 1990, and in the USA in the same time period approximately 43,000 new foundations have been created, which likewise comprise $57 \%$ of this legal form in existence (von Schnurbein 2010). At the same time it must be taken into consideration that foundations in Germany or Switzerland in contrast to the USA can operate as grant-making or operative organisation (Strachwitz 2010). Thus on

\footnotetext{
1 This applies likewise to Germany, Austria and Switzerland. Newer legal forms, especially the limited liability company and the public limited company, are negligible in this context, since most of them are used for the organisation of subordinate or outsourced operations.
} 
the basis of its activities it is often not apparent whether an organisation is an association or a foundation.

In addition to the clear increase in the number of foundations the number of the transformations of associations to foundations has also increased, as studies in Switzerland have shown. Often mentioned as reasons for these changes are governance issues, the safeguarding of wealth, independence and fund raising among institutional sponsors (von Schnurbein 2008). These transformations imply that the legal form is less a part of the identity of the organisation than increasingly a decision-making issue (Nowotny and Fida 2007).

According to the theory of 'institutional isomorphism' (DiMaggio and Powell 1983), processes of assimilation, such as the conversions just described, are a reaction to the changes in the organisational field that occur as a consequence of uncertainty, coercion or professionalization. Precisely the last aspect is in the context of nonprofit management research currently under discussion (Maier and Meyer 2011).

On the basis of these preliminary reflections, this article will investigate whether in nonprofit management research the legal form is adequately taken into consideration. Especially in view of the new attraction of the foundation the research question can be posed whether the legal form has a significant influence on the management of an organisation. With the aid of a multivariate regression analysis the influence of various management dimensions on NPO excellence will be exploratively measured in a sample of associations and foundations. For this purpose in the following remarks four management dimensions in accordance with a concept of Young's (2004) will first be discussed with the support of secondary literature and then hypotheses drawn therefrom. The method of collecting, processing and analysing data will be subsequently presented. In the process it should be noted at the outset that for the empirical verification of the research question it is essential to obtain a sample from NPOs that is homogeneous to the highest degree. In the summary it will be emphasised that with the aid of the results the conclusion can be drawn that the legal form has an influence on NPO management and in the present sample foundations can draw upon a strategic benefit in relation to their innovative capability that manifests itself in large degrees of organisational and financial excellence.

\section{Survey of secondary literature}

The demand for a more pronounced orientation of NPOs on business management methods and tools has developed from the basic principle that NPOs must strive for efficiency and effectiveness in achieving a successful implementation of the organisation's purposes. One reason for the orientation is the shortage of, or lack of access to, relevant resources (Schwarz and Lichtsteiner 2008). The securing of NPO-specific resources, such as donations, volunteers and honorary members, is currently very expensive, and cutthroat competition for such assets dominates the daily existence of these organisations. An additional reason is the increasingly critical stance of society in general towards NPOs. This change has led to an estrangement between NPOs and society in general that has increased the 
legitimation pressure on NPOs (Anheier 2003). In the application of management in NPOs it is repeatedly underlined that their special characteristics should be emphasised and the appropriate instruments adapted to, or newly developed for, the special tasks required (Schwarz 1996). An expressed criticism is also that too pronounced an orientation on management topics can endanger the important goals of NPOs. Managerialism thus offers, on the one hand, the chance of a more effective and efficient use of resources but, on the other, runs the risk of suffocating the important thematic objectives of the organisation by too rigidly applying the formal goals of business (Meyer 2008; Eikenberry and Kluver 2004). This is also shown in the fact that professionalization creates additional costs resulting especially from the increased monitoring of employees on the front (Parsons and Broadbridge 2004).

A possibility of operationalizing the designing of management is the differentiation of various management dimensions that are nevertheless intimately related to each other. Young's management concept (2004), developed on the basis of organisation theory derived from musical ensembles, comprises five management dimensions. ${ }^{2}$ An American concept will be employed, since all of the organisations in the sample are there understood to be charities. Thus NPOs must manage the areas of innovation, market niche, motivation, coordination and excellence. In the process the last dimension is a result of the useful and structured combination of the first four dimensions. For Young, excellence means that an organisation is excellent in the long term in which it masters the challenges of the previous four dimensions and weighs them against each other. In the next section the five management dimensions will be represented on the basis of theoretical considerations.

\subsection{Innovation}

Innovation means the implementation or adaptation of a new idea, task, activity or service that is new for the organisation concerned (Osborne 1998). Without development and change an organisation grinds to a halt and is at risk of sacrificing its existence. Jaskyte and de Riobo (2004) demonstrate in a study of Argentinian organisations that the openness to new methods and the adaptability to new times characterise innovative NPOs.

For both capabilities it is necessary that there are innovators within the organisation (Van de Ven 1986). Jaskyte (2004) in this context concludes that leadership style (e.g., transformational leadership) alone is not what strengthens the innovative capability of an organisation but rather what matters is making innovation an integral part of the organisation's culture.

In retrospect NPOs are associated not only with social novelty but also with innovations specific to the organisation. Especially in the case of foundations, however, the current discussion is highly controversial. On the one hand, it is argued that because of their independence from market and state, foundations can more easily implement innovations than other players in society can manage (Anheier and

\footnotetext{
${ }^{2}$ Based on systems theory Schwarz (2006) divides the management of an NPO into coordination, decision-making, organisation, leadership and innovation. Because of the historical development of association management, this division appears rather unsuitable for the following study, since the division was developed specifically for associations.
} 
Leat 2002; von Schnurbein and Timmer 2010). In addition, foundations have simpler organisational structures, since they do not have democratically elected decision-making bodies (von Schnurbein 2007). The non-existent accountability with respect to members, or similar parties, permits the assumption of higher risks (Toepler and Feldman 2003).

The innovation capability of associations, on the other hand, results less from decision-making structures and decidedly more from the flexibility of the organisation. Association structures provide, on the one hand, more stability than informal structures (Wollebaek 2009), but, on the other hand, the purpose and the mission of the associations are not so rigidly established as in a foundation, whose charter is scarcely alterable (Jakob et al. 2009). Innovation in associations can originate both top-down as well as bottom-up. Precisely in federalist structures new concepts or projects in individual regional units are often tested before they are transferred to the total organisation (Helmig et al. 2006).

\subsection{Market niche}

For Young (2004) the management dimension market niche means that NPOs must find a specific niche in which they can offer their services, i.e., primarily develop a strategy of specialisation. However, this assumes that the NPO is capable of analysing the market in order to discover unoccupied or promising niches. For this reason the proper estimation and reaction to the market situation and the strategic missions related thereto will be examined for this study as management dimensions.

In their survey of NPO management research Helmig et al. (2004) emphasise the increasing significance and percipience of marketing for NPOs. In the process distinctive features that distinguish NPO marketing from classical profit marketing are first of all to be taken into consideration. The manifold exchange groups represent an important difference, since NPOs are not only required to practice marketing with customers but also with resource providers such as volunteers, donors and so on (Purtschert 2005; Sargeant 2001). Thus in addition to communication and marketing strategies, fund raising and relationship marketing also belong to the central research themes in NPO marketing (Helmig et al. 2004). For the distinction between the management of associations and foundations the marketing strategy of NPOs should especially be taken into consideration.

Strategic planning provides an NPO with advantages in comparison to its competitors. Mazzarol and Soutar (2007) demonstrate for NPOs in the educational system that organisations with a clear strategy were more successful than those without one. This connection can also be demonstrated for NPOs in other sectors (Siciliano 1997).

In developing a market strategy NPOs in general prefer differentiation strategies developed in dependence on the milieu to a cost-based strategy (Mazzarol and Soutar 2007; Chew 2005). This preference is related to the fact that NPOs do not derive their legitimation from themselves but rather require the external corroboration of their stakeholders and especially their beneficiaries (Bryson et al. 2001). In addition, with the aid of a differentiation strategy, better competitive advantages can be worked out. A competitive advantage always exists when an organisation can 
offer its customers a quality product that costs less to produce than the customer is prepared to pay (Porter 1985). An NPO thus creates a competitive advantage when it succeeds in producing a higher value for the beneficiary at a lower cost than that of the competitor.

\subsection{Motivation}

Motivation includes all the tasks linked to the management of the persons involved (employees, volunteers, honorary members). Young (2004) emphasises the motivation of employees. The expression of good leadership is thus an excellent recruitment capability for the NPOs as well as a matter of high satisfaction for the honorary and full-time employees. On the basis of the numerous categories of those involved, leadership and motivation functions in NPOs have a particular complexity. After all, what is required is to motivate equally paid as well as unpaid employees with different interests and expectations. In the process it is assumed that intrinsic and extrinsic motivations govern all of those involved in NPOs. Intrinsic motives, such as support of the mission, individual values or participation, are in the process of becoming more important mainly for paid employees (Brown and Yoshioka 2002). In general leadership theory, a distinction between differing leadership styles is made. If previously the primary distinction was made between task-orientation and staff-orientation, in recent times the dividing line between transactional (target values) and transformational leadership (conviction) is being drawn. A meta-analysis including seventy-six studies has demonstrated, however, that staff orientation is especially important for the satisfaction with, and the effectiveness of, the leadership (Steyerer and Meyer 2010).

An additional important factor for successful leadership is the recruiting of volunteers. Field experiments have demonstrated that potential volunteers function effectively mainly when they obtain information on the support of the NPO and less from information on the excellence of the NPO or from information from existing volunteers (Boezeman and Ellemers 2008).

\subsection{Coordination}

This management dimension includes the development and design of the structures and processes of an organisation. At the same time, in relation to the different legal forms the most important feature is the manifestations of the leadership levels and the governance structures, since the design of the operative management is not directly influenced through the choice of the legal form. In the centre of the analysis is thus the coordination through decision processes, the composition, and the effectiveness of the board of management or foundation board as the central leadership- and decision-making body in the NPO (Callen et al. 2003).

The coordination through decision-making presents a central object for research on the contribution of the coordination system to the excellence of the organisation (Green and Griesinger 2006). Murray et al. (1992) introduce five different models as to how NPO management boards are run. In addition to the dominance through the president, fragmented power structures and impotent 
management boards, two models could mainly be verified in the empirical examination: on the one hand, management boards were significantly influenced by the corporate management, the decisions prepared and then implemented. The management board sanctioned decisions without being able to exert a significant influence (Cornforth 2003). On the other hand, there are management boards with balanced power structures. Decision-making is consensus oriented, and thus takes much longer, but is solid and stable in its implementation (Murray et al. 1992). Far-reaching changes are thus only achieved with difficulty, and new projects must be adopted by a majority.

In composing the management board the reputation of the board's members, representation and expert knowledge are competing aspects. A management board must represent the important stakeholders, make expert-oriented strategy decisions and act on behalf of NPOs in dealings with outside interests (Balser and McClusky 2005). In addition, the organisational structure represents a significant factor of influence in its composition (von Schnurbein 2009). Large organisations tend to have large management boards. At the same time it must be taken into consideration that heterogeneous management boards make a broad degree of knowledge and extensive networks possible, while at the same time potential conflict in committees increases (Brown 2005). An indirect influence of the composition of the board of managers on the excellence of the organisation can, however, scarcely be verified. Instead Callen et al. (2003) demonstrate that the membership of important creditors reduces the portion of overall costs.

Up to the present there is no uniform procedure for measuring the influence of the activities of the management board or the contribution of the board to the excellence of the organisation (Herman et al. 1997; Herman and Renz 2008). However, it is essential for a management board that works in accordance with governance criteria to evaluate and analyse the quality and effectiveness of its performance. In addition, in the communication with external stakeholders a clear measurement of the excellence of the management board helps to demonstrate transparency and in this way to earn a reputation for reliability (Gill et al. 2005).

It is a logical consideration that a successful board of management has a positive influence on the results of the association. However, the achievements have demonstrated that it is very difficult to ascertain this relationship in a scholarly fashion. The reason for this is to be found in the difficulty of comprehensively operationalizing both structures of excellence.

\subsection{Excellence}

For Young (2004) the implementation of the first four dimensions means a clear performance orientation that in the end helps the NPO overall achieve excellence. This last dimension is thus, as stated above, to be understood as the consequence of the other dimensions. There is, however, no consensus about what determines the excellence of an NPO or how it can be measured (Forbes 1998). Since NPOs always strive for a goal, qualitative contents in the measure of excellence assume a large significance as to why NPO excellence is determined situationally, perceived by different stakeholders differently, can be judged only on a 
comparative basis and is multidimensional (Herman and Renz 2008). Multidimensionality thus also entails that NPO excellence cannot be measured by means of a key performance indicator, but rather with the aid of several indicators that include financial excellence as well as programme- and stakeholder-related goals (Greiling 2009). As financial excellence, efficiency is measured as a rule of thumb in the sense of an input-output relation (Baruch and Ramalho 2006). The process orientation can theoretically be explained by the system approach that understands the internal functionality of an organisation as a significant excellence factor. In addition, however, the trade-offs and the assessments of the relevant stakeholders are also taken into consideration (Schwarz 2003). In the research design of this examination the multidimensionality of the NPO excellence will be taken account of in the manner that, on the one hand, the financial excellence and, on the other hand, the programme excellence targeted at objective goals are ascertained on the basis of the assessments question (Brown 2005); (see Table 7 in the “Appendix".).

\section{Research design}

The present study is intended to examine the influence of the legal form on management dimensions and their correlation to NPO excellence. In order to answer this research question, research hypotheses will be developed on the basis of the previously described survey of secondary literature as well as with the aid of theoretical considerations based upon neo-institutional theories (Meyer and Rowan 1977; DiMaggio and Powell 1983). DiMaggio and Powell (1983) explain the tendency towards homogeneity of organisations by means of three forms of institutional isomorphism: first, coercive isomorphism originates in formal or informal pressure or compulsion that is exerted upon an organisation; second, mimetic isomorphism results from the orientation on traditional responses to uncertainty; finally, normative isomorphism can be explained by the influence of professionalization within organisations and business sectors. The theory of institutional isomorphism is often applied to NPOs, since in contrast to businesses they are scarcely exposed to competitive isomorphism (DiMaggio and Powell 1983). The following analysis questions, on the one hand, the homogeneity of the NPO legal form and analyses, on the other, the effects of management on the excellence of the organisation. In the first case the legally structured legal forms imply different consequences in the organisational design that may involve coerced isomorphism. In the second case normative or mimetic isomorphisms can occur because of professionalization and uncertainty (Maier and Meyer 2011). The theory of institutional isomorphism thus offers a useful basis for the formulation of hypotheses. Research hypotheses are intended to describe the relationship between the represented management dimensions as independent variables and the programme as well as the financial excellence as dependent variables. Finally, in this section the method and descriptive results of the sample will be introduced. 


\subsection{Research hypotheses}

For the analysis of the data two regression models will be calculated subsequently for the two dependent variables. Accordingly, the hypotheses for both Model A (financial excellence) and B (programme excellence) will be developed (see Table 1 below).

The developing competition in many classic NPO sectors compels NPOs to practice intensified market-oriented management, which means to actively create a marketing mix of price, distribution, promotion, product/service provision as well as personnel and physical evidence (Bruhn 2005). Market management also includes acquiring an advantage in comparison to other organisations by pursuing systematic market observation and analysis. In the case of NPOs these benefits relate not just to the performance output but also to the same degree to the procurement of resources such as donations or voluntary personnel (Purtschert 2005). Because of their lean and hierarchically organised structures foundations are capable of reacting quickly to market changes and making the necessary adaptations. For this reason it is easier for foundations to adapt in the sense of mimetic isomorphism to economic competitors in the market and thus to react to new trends. The democratic decisionmaking paths in associations, on the other hand, hamper a quick reaction to changes in the market situation, and mimetic processes thus proceed more slowly. The excellence of foundations is, therefore, more strongly influenced by the adaptation to the market situation than is that of associations.

$H 1_{A}$ : Foundations can react faster to market changes. Market adaptations thus have a more positive effect on financial excellence in foundations than in associations

Table 1 Hypotheses matrix on management dimensions and factors of excellence

\begin{tabular}{|c|c|c|}
\hline \multirow{2}{*}{$\begin{array}{l}\text { Management } \\
\text { dimensions }\end{array}$} & \multicolumn{2}{|l|}{ Factors of excellence } \\
\hline & Model A: Financial excellence & Model B: Programme excellence \\
\hline Market Niche & $\begin{array}{l}\mathrm{H} 1_{\mathrm{A}} \text { : Foundations can react faster to } \\
\text { market changes. Market adaptations } \\
\text { thus have a more positive effect on } \\
\text { financial excellence in foundations than } \\
\text { in associations }\end{array}$ & $\begin{array}{l}\mathrm{H} 1_{\mathrm{B}} \text { : Foundations can react faster to } \\
\text { market changes. Market adaptations } \\
\text { thus have a more positive effect on } \\
\text { programme excellence in foundations } \\
\text { than in associations }\end{array}$ \\
\hline Innovation & $\begin{array}{l}\mathrm{H} 2_{\mathrm{A}} \text { : The capacity for innovation } \\
\text { promotes financial excellence more } \\
\text { strongly in foundations than in } \\
\text { associations }\end{array}$ & $\begin{array}{l}\mathrm{H} 2_{\mathrm{B}} \text { : The capacity for innovation } \\
\text { promotes programme excellence more } \\
\text { strongly in foundations than in } \\
\text { associations }\end{array}$ \\
\hline Coordination & $\begin{array}{l}\mathrm{H} 3_{\mathrm{A}} \text { : Coordination has a smaller } \\
\text { influence on financial excellence in } \\
\text { foundations than in associations }\end{array}$ & $\begin{array}{l}\mathrm{H} 3_{\mathrm{B}} \text { : Coordination has a smaller } \\
\text { influence on programme excellence in } \\
\text { foundations than in associations }\end{array}$ \\
\hline Motivation & $\begin{array}{l}\mathrm{H} 4_{\mathrm{A}} \text { : Good motivation has a larger } \\
\text { influence on financial excellence in } \\
\text { associations than in foundations }\end{array}$ & $\begin{array}{l}\mathrm{H} 4_{\mathrm{B}} \text { : Good motivation has a larger } \\
\text { influence on programme excellence in } \\
\text { associations than in foundations }\end{array}$ \\
\hline
\end{tabular}


$H_{B}$ : Foundations can react faster to market changes. Market adaptations thus have a more positive effect on programme excellence in foundations than in associations

Since foundations do not have shareholders, members or other direct stakeholders, they are said to have a high capacity for innovation (Anheier and Leat 2002). Foundations are predestined to make risky investments that the state or the market would not undertake. This observation is derived, on the one hand, from the high degree of decision-making authority of the foundation board as mostly the sole body that makes decisions and, on the other, from the non-existent accountability to the stakeholders. State supervision performs in each case only the monitoring of formal accuracy, but does not engage in the assessment of the foundation's substantive efficacy. Studies in the USA have, however, demonstrated that foundations scarcely or seldom exercise their innovative functions. Finally, innovation does not happen on its own, but only as the result of - especially external-impulses. In associations, on the other hand, the elected committees must repeatedly be endorsed or important decisions must be taken by the general assembly. This makes the decision process more difficult and leads to a consensus- and compromise-oriented leadership process to which innovation can quickly be sacrificed. At the same time, however, the members are also an important innovative factor, since through their participation or resistance they can insist on change (Hirschman 1987). For both legal forms there are grounds to be derived from the secondary literature for and against innovation. From a neo-institutional perspective there is a certain dichotomy between innovation and isomorphism. While as explained above innovation signifies the implementation of a new idea, isomorphism stands primarily for the adaptation to conventions and the search for legitimacy by the adoption of existing structures. Even when a strategy of adaptation can be successful in the short run, innovation as a factor of excellence for the survival of an organisation in the midst of social change is essential (Ergenzinger and Krulis-Randa 2005). Because of their democratic structures there is a stronger tendency towards isomorphic processes in associations than in foundations (Aberg and von Essen 2010). Innovations can thus be more successfully and more efficiently implemented in foundations than in associations, where more effort to convert opponents to the party line must be made. For this reason foundations have a greater potential to implement innovations effectively. This expectation is formulated in Hypothesis 2.

$H 2_{A}$ : The capacity for innovation promotes financial excellence more strongly in foundations than in associations

$H 2_{B}$ : The capacity for innovation promotes programme excellence more strongly in foundations than in associations

In the design of coordinating systems, especially the governance structures, associations, because of the democratic structures, have an advantage over foundations. The design of checks and balances, as well as the application of more transparent information mechanisms, is required and expected from the members (Purtschert 2004). A good governance structure promotes the exchange with the grass roots and increases the sense of cooperation in the whole organisation. In this way a mutual fruition of organisational goals is promoted. In the areas of separation of powers and participation, associations disclose higher degrees of competency 
than do commercial enterprises and are thus granted the function of a role model (Schwarz and von Schnurbein 2005; Frey and Benz 2007). Governance committees in foundations are, on the other hand, often unbalanced or limited in their possibilities, which as a consequence can foster the accrual of completed staff work and a power shift in favour of the operative leadership level. The limited legal provisions, the composition regulations established in the charter for the foundation board, as well as co-optation as a typical renewal mechanism often impede adaptations to new milieu conditions. Because of professionalization normative isomorphisms are thus frequently restricted in foundations to operational business activities, but not to the governance system. Hypothesis 3 thus assumes a strong influence of the governance structures upon the organisational excellence of associations in comparison to foundations.

$H 3_{A}$ : Coordination has a smaller influence on financial excellence in foundations than in associations

$H 3_{B}$ : Coordination has a smaller influence on programme excellence in foundations than in associations

Because of the lack of basic structures, foundations tend towards more pronounced administrative structures than those of associations. In foundations more work by paid personnel must be accomplished, since in contrast to associations the members do not comprise primary recruitment sources of volunteers. Accordingly, because of the democratic structures the managerial functions in associations are often more complex. In the end, the satisfaction of both staff and honorary (volunteer) personnel has to be considered and assured. As a result the significance of the management activity for the complete excellence of the organisation increases. On the one hand, in associations often the competing opinions between membership groups must be balanced, and, on the other, the cooperation of volunteers requires special management competency (Harris 1998). Because of these diverse managerial responsibilities associations are more strongly dependent on the development of institutional rules and rituals. As a result the professionalized business operations and the members of an association tend to separate; this means that the formalised structures do not conform to the real processes, further enhancing the importance of situationally well adapted leadership (Meyer and Rowan 1977). Hypothesis 4 thus assumes that a high degree of motivation more positively influences the organisational excellence in associations than in foundations.

$\mathrm{H}_{\mathrm{A}}$ : High motivation has a larger influence on financial excellence in associations than in foundations

$\mathrm{H}_{\mathrm{B}}$ : High motivation has a larger influence on programme excellence in associations than in foundations

\subsection{Methodology}

For the verification of the hypotheses developed from theory, a sample from German-speaking Swiss NPOs was compiled that either fulfils the ZEWO Seal of Approval or the SEA Code of Honour. The ZEWO Seal of Approval, which at the date of the survey was held by 495 organisations, is the most important certificate of 
donation for organisations seeking funds. Since the ZEWO Seal of Approval (among others) is not awarded to organisations with a religious-proselytising purpose, the Swiss Evangelical Alliance developed for these organisations their own code of ethics that fulfils the same function as the ZEWO Seal of Approval covers. A total of eighty organisations are signatories of the SEA Code of Honour. The restriction to organisations with a certificate of donation was undertaken in order to limit the heterogeneity of the organisations: first, in the case of NPOs with a certificate of donation it can be assumed that they all undertake the fund raising and develop it into active marketing; second, for the acquisition of the Seal of Approval certain minimum standards in the management of the organisation must be fulfilled, e.g., in relation to the governance or the rendering of accounts. For the study of the influence on management dimensions on the excellence of the organisation it is important that management consciously be applied in the first place. Altogether 520 German-speaking NPOs in the late summer of 2009 were contacted. They were sent a four-page questionnaire that contained descriptive information relating to the NPO and assessment questions pertaining to the management dimensions and the excellence of the organisation. The evaluations were presented as a Likert Scale with five rating possibilities ranging from 'describes the case accurately' to 'is not at all the case'.

The recording of the excellence of the organisation was modelled on Brown (2005) with five assessment questions (see Table 7 in the "Appendix") that primarily query the performance excellence with customers. Moreover, the financial excellence with the code 'cost covering amount' (total costs/total return) was calculated. At the same time the fact was taken into account that NPOs are not primarily oriented on profit or returns, but rather that the financial means are used for the fulfilment of organisational goals. In addition, by means of the code the large differences in the financial volume of the NPOs, in part, are put into perspective, thus increasing the degree of comparability. For the performance measure of fund raising, subsidies, and their own earnings, the proportion of the total yield in each case was consulted (see Table 8 in the "Appendix").

The analysis is based upon factor analyses and binary correlation analyses. The reliability of the indicator of the four management dimensions and of the organisational excellence in each case was verified with the aid of an explorative factor analysis (Robinson et al. 1991). According to Peter (1979) factor loadings of at least 0.4 per indicator are in this connection necessary. For all four management dimensions and the organisational excellence in each case a factor could be determined (see Table 2). The factor loadings of the individual indicators are located at not less than 0.57. Moreover, the results of the Kaiser-Mayer-Olkin measure (KMO) show a quite good suitability for a factor analysis (Kaiser 1974). In addition, all the twenty-seven indicators together as well as the indicators of the individual management dimensions in each case show an alpha coefficient of at least 0.77 . In the differentiation according to associations and foundations an alpha coefficient of at least 0.73 was reached. For this reason the sample satisfies the requirements of an adequate differentiation between the management dimensions; this means a minimum value in the case of Cronbach's alpha of 0.7 (Nunnally 1978; Hair et al. 2006). 
Table 2 Quality of the factors

\begin{tabular}{lcllc}
\hline Factor & Number of items & Breadth of factor loadings & Cronbach's alpha & KMO \\
\hline Market niche & 5 & $0.63-0.79$ & 0.77 & 0.82 \\
Innovation & 6 & $0.57-0.80$ & 0.80 & 0.80 \\
Coordination & 10 & $0.56-0.85$ & 0.89 & 0.88 \\
Motivation & 6 & $0.61-0.75$ & 0.79 & 0.81 \\
Organisational excellence & 5 & $0.75-0.77$ & 0.80 & 0.80 \\
\hline
\end{tabular}

Altogether 180 questionnaires were returned (of which one questionnaire could not be used for the data evaluation). Even so the response rate amounted to $N=179$ or $34.4 \%$, which is a very satisfactory result and supports the representative character of the study. The distribution between the two seals of approval in the sample (81.6\% ZEWO; $18.4 \%$ SEA) corresponds more or less to the ratio of the population. Likewise the distribution of the fields of activity corresponds to the general structure of the Swiss NPO sector on the whole, in accordance with which social affairs and health care are the dominant spheres of activity (Helmig et al. 2010).

The sample comprises 126 associations (70.4\%), fifty-one foundations (28.5\%) and two cooperatives $(1.1 \%)$. The cooperatives, however, were not included in the analysis of the management dimensions. The reporting year 2008 for this survey coincided with the financial slump, and for this reason there were very large differences in the key financial indicators. In the surplus the median lies almost in the positive sector at 3,000 CHF, but there are large fluctuations of 11.8 million $\mathrm{CHF}$ in losses up to 4.4 million in profit. The quartile figures make clear, however, that there is a clear concentration in a narrow corridor between $-13,000$ and 60,000 $\mathrm{CHF}$. In the case of foundations and associations these figures result thereby in a differentiated picture: in the case of foundations the median of 5,834,684 CHF lies far above the corresponding value for associations of 1,750,000 CHF. The largest profit and the highest loss are recorded in the sample of the foundations, which thus also exhibit a far greater distribution (see Table 8 in the "Appendix").

Precisely $83.2 \%$ or 149 of the organisations hold the ZEWO-Seal of Approval, $18.4 \%$ or thirty-three are SEA certification. Four organisations in the sample hold both quality certificates. These figures correspond to a very large extent to the basic population where seventy-eight organisations $(15 \%)$ hold the SEA Code of Honour.

In the case of responding persons more than $90 \%$ are members of the executive board, the management board or the foundation board. The average age is 51.9 years, and $34.6 \%$ of those answering the questionnaire are women. In Table 3 additional descriptive results of the sample are summarised.

\section{Results}

In Table 4 the results of the bivariate correlation analyses are presented. Generally, only weak to medium correlations between the independent variables exist, which 
Table 3 Descriptive results of the sample

\begin{tabular}{|c|c|c|}
\hline Characteristic feature & $\begin{array}{l}\text { Number } \\
(N=179)\end{array}$ & Percentage \\
\hline \multicolumn{3}{|l|}{ Area of Activity (multiple areas possible) } \\
\hline Social services & 84 & $46.9 \%$ \\
\hline Health care & 74 & $41.3 \%$ \\
\hline Education/research & 40 & $22.3 \%$ \\
\hline Development cooperation & 39 & $21.8 \%$ \\
\hline Migration & 25 & $14.0 \%$ \\
\hline Religion/mission & 22 & $12.3 \%$ \\
\hline Lobbying/advocacy & 19 & $10.6 \%$ \\
\hline Employment agency & 16 & $8.9 \%$ \\
\hline Environmental protection/animal welfare & 7 & $3.9 \%$ \\
\hline \multicolumn{3}{|l|}{ Geographic orientation } \\
\hline Local/regional & 38 & $21.2 \%$ \\
\hline Cantonal & 56 & $31.3 \%$ \\
\hline National & 58 & $32.4 \%$ \\
\hline International & 36 & $20.1 \%$ \\
\hline \multicolumn{3}{|l|}{ Membership development in the last 5 years $(N=117)$} \\
\hline Positive & 47 & $40.2 \%$ \\
\hline Unchanged & 39 & $33.3 \%$ \\
\hline Negative & 31 & $26.5 \%$ \\
\hline \multicolumn{3}{|l|}{ Fund raising development in the last 5 years $(N=147)$} \\
\hline Positive & 63 & $42.6 \%$ \\
\hline Unchanged & 31 & $20.9 \%$ \\
\hline \multirow[t]{2}{*}{ Negative } & 54 & $36.5 \%$ \\
\hline & Middle value & $\begin{array}{l}\text { Standard } \\
\text { distribution }\end{array}$ \\
\hline $\begin{array}{l}\text { Number of members on the board of directors/foundation } \\
\text { board }\end{array}$ & 8 & 3.2736 \\
\hline Number of members in the company management & 3 & 2.2126 \\
\hline Number of staff $(N=177)$ & 81 & 348.9668 \\
\hline Number of volunteers $(N=148)$ & 501 & 3661.0182 \\
\hline
\end{tabular}

implies a sufficient difference in the coefficients. In addition, tests for multicollinearity have verified the independence of the factors. The condition indices amounted to a maximum of between 2.054 and 2.178, and also in the proportion of variance no indications of collinearity could be found. Additional statistical information on the individual items of the factors are listed in Table 7 in the "Appendix".

Between the two dependent variables there are only weak correlations, whereas the negative correlation in the factor coordination in the sample of the associations is surprising. A possible explanation for this correlation is the pressure exerted by the members not to generate large surpluses. Generally, the weak correlation 
Table 4 Results of the bivariate correlation analyses between management dimensions and factors of excellence

\begin{tabular}{|c|c|c|c|c|}
\hline $\begin{array}{l}\text { Market } \\
\text { niche }\end{array}$ & Motivation & Coordination & Innovation & $\begin{array}{l}\text { Programme } \\
\text { excellence }\end{array}$ \\
\hline
\end{tabular}

Sample overall $(n=177)$

Market niche

1.000

Motivation

$0.326^{* *} \quad 1.000$

Coordination

0.088

$0.445^{* *}$

Innovation

$0.300^{* *}$

$0.381^{* *} 0.384^{* *}$

Programme excellence

$0.332^{* *}$

$0.352^{* *} \quad 0.284^{* *}$

1.000

Financial excellence

$0.244^{* *}$

$0.094-0.084$

$0.370^{* *}$

1.000

Sample associations $(n=126)$

Market niche

1.000

Motivation

$0.385^{* *}$

1.000

Coordination

$0.177^{*}$

$0.444^{* *} \quad 1.000$

Innovation

$0.289^{* *}$

$0.343^{* *} \quad 0.399^{* *}$

Programme excellence

$0.308^{* *}$

$0.339^{* *} 0.334^{\text {*** }}$

1.000

Financial excellence

0.163

$0.015 \quad-0.161$

$0.285^{* *}$

1.000

Sample foundations $(n=51)$

Market niche

1.000

Motivation

0.260

1.000

Coordination

$-0.082$

$0.436^{\text {** }}$

Innovation

$0.389^{* *}$

$0.462^{\text {** }} 0.330^{*}$

1.000

Programme excellence

$0.397^{* *}$

$0.420^{* *} \quad 0.175$

$0.572^{* *}$

Financial excellence

$0.378^{*}$

$0.260 \quad 0.028$

$0.643^{* *}$

1.000

$* p<0.05 ; * * p<0.01$

Table 5 Regression model with the dependent variable financial excellence

\begin{tabular}{|c|c|c|c|c|c|c|}
\hline \multirow[t]{3}{*}{ Model A } & \multicolumn{6}{|c|}{ Dependent variable: financial excellence } \\
\hline & \multicolumn{3}{|c|}{ Foundations } & \multicolumn{3}{|c|}{ Associations } \\
\hline & $B$ & SE b & $p$ & $b$ & $\mathrm{SE} \mathrm{b}$ & $P$ \\
\hline Constant & 1.032 & 0.034 & 0 & 1.034 & 0.021 & 0 \\
\hline Market niche & 0.050 & 0.036 & 0.172 & 0.042 & 0.026 & 0.104 \\
\hline Innovation & $0.190 * *$ & 0.039 & 0 & 0.007 & 0.023 & 0.782 \\
\hline Coordination & -0.053 & 0.04 & 0.195 & $-0.045^{*}$ & 0.024 & 0.062 \\
\hline Motivation & 0.013 & 0.056 & 0.811 & 0.007 & 0.026 & 0.784 \\
\hline$R^{2}$ & 0.483 & & & 0.062 & & \\
\hline Adj. $R^{2}$ & 0.432 & & & 0.025 & & \\
\hline $\mathrm{F}$ & 9.359 & & 0 & 1.661 & & 0.165 \\
\hline $\mathrm{N}$ & 45 & & & 105 & & \\
\hline
\end{tabular}

Bold values indicate statistical significance $(p=0.01)$

$* p<0.05 ; * * p<0.01$ 
Table 6 Regression model with the dependent variable programme excellence

\begin{tabular}{|c|c|c|c|c|c|c|}
\hline \multirow[t]{3}{*}{ Model B } & \multicolumn{6}{|c|}{ Dependent variable: programme excellence } \\
\hline & \multicolumn{3}{|c|}{ Foundations } & \multicolumn{3}{|c|}{ Associations } \\
\hline & $B$ & SE b & $P$ & $B$ & SE b & $P$ \\
\hline Constant & -0.014 & 0.124 & 0.909 & 0.002 & 0.08 & 0.977 \\
\hline Market niche & 0.165 & 0.130 & 0.211 & 0.201 & 0.097 & $0.04 * *$ \\
\hline Innovation & $0.439 * *$ & 0.147 & 0.004 & 0.109 & 0.092 & 0.237 \\
\hline Coordination & -0.037 & 0.144 & 0.799 & 0.179 & 0.095 & $0.062^{*}$ \\
\hline Motivation & 0.232 & 0.174 & 0.189 & 0.143 & 0.092 & 0.122 \\
\hline$R^{2}$ & 0.387 & & & 0.2 & & \\
\hline Adj. $R^{2}$ & 0.332 & & & 0.174 & & \\
\hline $\mathrm{F}$ & 7.094 & & 0 & 7.514 & & 0 \\
\hline $\mathrm{N}$ & 50 & & & 125 & & \\
\hline
\end{tabular}

Bold values indicate statistical significance $(p=0.01)$

$* p<0.05 ; * * p<0.01$

confirms the multidimensionality of the NPO excellence, since the data in programme excellence and financial excellence do not yield the same results (Herman and Renz 2008).

In Table 5 the results of the regression model with the dependent variable financial excellence are presented in composite form. Here a clear difference between associations and foundations can be established. The total model is significant only for foundations and explains $43.2 \%$ of the distribution. Of the management dimensions innovation contributes most clearly to the explanation and is likewise significant. The factors market niche and motivation have, to be sure, a positive explanatory power, but it is in each case weak. The factor coordination even shows a negative influence on the financial excellence of foundations. This means that foundations can increase their financial excellence most clearly through the use of innovation potentials. In the model with associations all the factors show only a very small explanatory power. Here, likewise, the factor coordination shows a negative influence on financial excellence. This can be mainly explained by the financing strategy of the organisation investigated. All things considered, internal structures play no role in the payment decisions of donors; what really counts is that more elaborate motivation structures have a negative influence on the acceptance of the donors through the increased administrative costs that result (Aldrich 2009).

On the basis of the higher explanatory power in the foundations the results confirm the Hypotheses $1_{\mathrm{A}}$ und $2_{\mathrm{A}}$. Innovation capability and market adaptation have a stronger influence on the financial excellence in foundations than in associations. Because of the lack of basic democratic processes in foundations, the full-time staff have a larger degree of creative freedom and can assume larger risks on their own, which is essential for the generation of innovative potentials (Toepler 
and Feldman 2003). Hypotheses $3{ }_{\mathrm{A}}$ and $4_{\mathrm{A}}$ must, on the other hand, be rejected because of the weak explanatory power of the total model in the case of associations.

The results for Model $\mathrm{B}$ with the programme excellence as dependent variable are displayed in Table 6. The total model is significant for both foundations and associations, but the explanatory power in the case of foundations is almost twice that of associations. In the foundations innovation, market niche and motivation have a positive influence on programme excellence. Again, the explanatory power of the factor innovation is the highest and, in addition, is significant. Surprising is the higher influence of the factor motivation in comparison to the factor market niche. As in Model A the influence of the factor coordination is negative, even if only very weakly so. In the associations the difference between the four factors is less clear and in their contribution to the explanatory power almost the reverse of the model of the foundations. Here the factor market niche has the strongest influence, followed by the factor coordination. While these two factors are significant, the two factors innovation and motivation have simply a positive but not a significant influence.

On the basis of these results Hypothesis $1_{\mathrm{B}}$ is in part rejected, since the explanatory power of the factor market niche assumes the highest value in the associations, even though the total model in the case of the associations shows a clearly smaller coefficient of determination. Hypotheses $2_{\mathrm{B}}$ and $3_{\mathrm{B}}$, however, are confirmed. While in the case of foundations the innovation ability has a greater influence on the programme excellence than in the case of associations, the influence of the factor coordination in the case of associations is more important than in foundations. The democratic, multi-layered and thus complex decisionmaking structures in associations are an important difference between the two legal forms (Schönenberg 2009). Therefore, it is understandable that associations profit from good governance structures (Tschirhart 2006), while for foundations these management dimensions have the smallest significance in connection with programme excellence. Hypothesis $4_{\mathrm{B}}$ must, on the other hand, be rejected, since the influence of the factor motivation in foundations turns out to be stronger than in the case of associations. An explanation as to why Hypothesis $4_{\mathrm{B}}$ must be discarded could depend upon the fact that the significance of the high degree of motivation of the full-time staff is generally estimated to be more important than the management of volunteers and honorary staff. Thus the satisfaction of the full-time staff in both the associations $(r=0.37 ; p<0.01)$ and in the foundations $(r=0.38 ; p<0.01)$ is of great significance for programme excellence. While in the associations the satisfaction of the honorary staff forms the second largest influence factor, the existence of a unified motivation concept $(r=0.36 ; p<0.01)$ in the case of foundations is a strong factor comparable to the satisfaction of the full-time staff. The satisfaction of the honorary staff, in contrast, shows no significant influence on the organisational excellence of the foundations. In light of the fact that foundations are more strongly dependent on full-time staff than associations are, the negative result of Hypothesis $4_{B}$ seems plausible. 


\section{Discussion and summary}

Judging the results of this study requires subtlety, since the quality of the results for the sample of the foundations and the associations turned out to differ considerably. Especially in the regression model with financial excellence as dependent variable, Hypotheses $3_{\mathrm{A}}$ and $4_{\mathrm{A}}$ are rejected primarily on formal grounds. In the case of Hypothesis $4_{\mathrm{B}}$ a plausible explanation for the contradictory result in the theoretical considerations can be adduced. On the whole the results of the study confirm the necessity of a management orientation for a successful NPO. However, the measured correlations are not very strong, a circumstance which reduces the explanatory power of the results. This circumstance can be attributed to the complexity of NPO goals. An effective mode of operation alone is insufficient to guarantee success as an NPO. The achievement of concrete goals, as well as the consideration of the diverse stakeholder interests, likewise determines the track record of an NPO (Greiling 2009).

It can moreover be derived from the ascertained connections that the financial excellence of an NPO is especially dependent on its ability to implement innovations and to estimate the market situation and less on efficient structures and leadership behaviour within the organisation. Here the fund raising orientation of the investigated NPOs whose financial resources depend upon external sources and not directly upon the readiness of the beneficiaries to pay is noticeable. An NPO can thus be successful in fund raising, even when the quality of the service provision does not correspond, factionalism within the organisation exists or the internal structures are inefficiently developed. In the case of programme excellence that includes aspects of the service provision, it is clear from the results that a comprehensive achievement of objectives in NPOs can not be reduced merely to financial indicators and fund raising results.

In order to increase the significance of future studies in relation to financial excellence, however, several series stretching over several years should be employed (Bowman 2006). An additional limitation results from the national relation to the legal bases. The legal form comparison from Switzerland can thus not be directly transferred to other countries. However, the results provide grounds to conduct research on the influence of legal factors on NPO management in other countries as well. Finally, in the case of a generalisation of the results it should be taken into consideration that a comparatively small sample of NPOs is being dealt with but that in relation to the quality certificates and fields of activity it corresponds to the structure of the basic population.

The central insight of this study, however, is the clear difference between the legal forms, association and foundation, which affects the influence of the management dimensions on the factors of excellence, especially on programme excellence. As a reminder it should once again be mentioned that in all the cases of the organisations in the sample, we are dealing with fund-raising organisations in the social sector that basically fulfil similar activities, so that from outside it is not easily observable whether an association or a foundation is involved. Because of the wide-ranging equality of treatment in the tax law assessment of foundation and 
association in Switzerland, as mentioned at the beginning, fiscal factors can be excluded as a motive for the choice of a certain legal form.

The clear and higher explanatory power of the regression model in the case of foundations thus permits the conclusion that foundations in comparison to associations have a management advantage that can be explained preponderantly by their different structures. From the perspective of institutional isomorphism the coercive adaptations to the legally regulated forms foundation and association are stronger than the management adjustment in the organisational field of the fundraising relief organisations.

The lack of basic democratic elements simplifies the decision processes in foundations and permits a more efficient motivation of the organisation. The great difference in the innovative capability especially demonstrates this difference. Foundations can quickly implement innovations as soon as the necessary decisions are made, whereas in the case of associations the decision-making process, especially in the case of innovations, is often very cumbersome and consensus oriented in order to ensure broad approval (Schwarz et al. 2009). On the basis of this investigation no clear insights for the management dimension market niche can be ascertained. The milieu of the NPOs is today subject to increasingly frequent changes; this development requires more rapid adaptation processes affecting foundations and associations equally. The ability to adapt to the market thus has a positive influence on the excellence of the programme for both foundations and associations. This circumstance can also be explained by the fact that professionalization occurs cross-organisationally in the whole branch and in this respect normative isomorphisms affect foundations and associations.

The results for the management dimension motivation turned out to be contrary to all expectations. Here the influence on programme excellence is also larger in foundations than in associations. An initial explanatory attempt is that because of the lack of membership basis, foundations can not so easily recruit volunteers as associations can. For this reason they are more strongly reliant on full-time staff for the provision of services. The results of the study appear to indicate that the motivation of full-time staff was regarded as more important by the management than the motivation of honorary staff, and for this reason because of their structures foundations here also have an advantage. This attempt to explain this feature must, however, be substantiated by additional studies.

The association in this study was able to show clear advantages only in the management dimension coordination. Good governance structures and decisionmaking processes decidedly contribute more to the excellence of the organisation in associations than in foundations. Since associations basically have higher coordination costs, this result is plausible. Thus a main emphasis in federation and association research is in the area of decision-making and decision-evaluation (Schwarz 1996). The legal form of the foundation, on the other hand, is often chosen exactly because of the simple structural guideline. Thus it can be maintained that foundations are driven by innovation, while associations have their strengths in the design of their internal structures and processes. 


\subsection{Implications for additional research}

The representative character of the sample and the robustness of the analysed data permit some significant implications to be derived from this investigation that might prove useful for research and practice. As was made clear at the beginning, the legal form in its significance for management criteria in NPOs has scarcely been taken into consideration. From the neo-institutional perspective this state is reasonable, since according to Meyer and Rowan (1977) the formal structures and rules can be separated from the actual implementation. In this respect it would have been expected that fund-raising NPOs show some homogeneous characteristics of management dimensions. The results of the investigation have shown, however, that the legal form definitely has an influence on the management of an NPO. Separation of the management activities from the underlying legal form is thus less possible than was implicitly assumed up to now in NPO management theory. Here it appears that the management approaches often developed for American charities cannot be transferred tel quel to the continental European context.

The empirical results of the study have shown, on the one hand, that mimetic, coercive and normative isomorphisms can be used to explain the similarities and differences among foundations. Even if it was not the direct research purpose of this study, the results nevertheless confirm earlier studies that view coercive isomorphisms as being anterior to other isomorphic processes (Verbruggen et al. 2011). In the current case the choice of the legal form (and the laws connected to it) leads to differentiations in additional isomorphic processes, thus, for example in the coordination of the organisation or the adaption to the market. Generally, isomorphic processes in NPOs are supported by the circumstance that NPO excellence can be measured only with difficulty. In the case of associations this circumstance manifests itself in the fact that through the adaptation to comparable organisations, the pressure of accountability on the members can be somewhat reduced. This especially promotes mimetic isomorphisms, that is, adaptations that occur as a result of the suspicion of an association's inadequacy. These can implicitly or explicitly take place and are not necessarily the result of a specific strategic decision. On the other hand, the use and implementation of innovation potentials in foundations permit a more independent development. This is a consequence of the legally anchored independence of foundations that have no members or owners. The explorative character of this investigation does not permit more than the assumption that a field of organisations, though superficially homogeneous, is in its management design not necessarily subject to the same isomorphic processes, but rather that specific institutional characteristics can cause differentiated developments. This recognition is of great importance, especially for the theoretical foundation and exploration of the increasing dissolution of sector boundaries between market, state and the third sector (Anheier et al. 2011). The present study makes clear that NPOs in the same area of activity have different management challenges that result from their formative structure. These differences should be given more attention in the future. Thus the additional criteria specific to the organisation, such as age, size or activity radius, are imaginable as additional 
management-critical factors. (Cornforth and Simpson (2003)) demonstrate, for example, that the size of the organisation has an influence on governance structure.

In relation to the legal form the question arises as to how far the differences worked out in this article can be enlisted as explanatory approaches for the increasing transformations of associations to foundations taking place at present (von Schnurbein 2008). While the implementation of such transformations has been investigated (Schönenberg 2009), an additional critical assessment is lacking as to what extent the functionality of the NPO sector is changed through reduced participation and what influence, conversely, the social milieu has on the resolutions. The great significance of the capacity for innovation in the case of foundations likewise offers scope for in-depth studies. Thus the question arises as to whence foundations derive their power of innovation. In contrast to associations, foundations lack an important barometer of opinion in the form of members providing their input. Loss of membership ('exit') and membership protests ('voice') are significant moving forces in the processes of change (Hirschman 1987). The question occurs as to how foundations maintain their capacity for innovation. This is also a matter of interest over time. Since a majority of the foundations in Switzerland-but also as well in other countries such as Germany or the USA-has been founded in the last 20 years, it must be shown for the future how foundations maintain their innovative strength.

\subsection{What can NPOs learn?}

This study has ascertained certain useful findings for the management of foundations and associations in their practical functions. Foundations can increase their potential for excellence when they facilitate innovations and invest in high motivation of the full-time staff. In the case of associations, however, the internal governance is the first thing to be regulated. For organisations whose activities are highly novel and who must first of all establish themselves, the legal form offers foundations a strategic advantage in comparison to the association, since the former permits quicker decisions paths and long-term goal setting. On the other hand, associations are better suited because of their basic democratic structures to provide a balance of interests between different stakeholder groups.

In addition, it can be derived from the results that NPOs ought to create more scope for innovations and a flexible designing of objectives to support their longterm organisational excellence. A good market understanding and the analysis of the competition promise positive effects on financial excellence. This should be valid to a high degree for fund-raising activities. What the differing results in financing and programme excellence do make clear is that NPOs must enforce multi-dimensional testing of results that include financial and concrete criteria. Otherwise, an NPO runs the risk of drawing false conclusions from a monitoring of excellence.

\section{Appendix}

See (Tables 7, 8). 
Table 7 Individual indicators for management dimensions and organisational excellence

\begin{tabular}{|c|c|c|c|c|c|}
\hline Items & $N$ & $r$ & $p$ & Mean & $\mathrm{SD}$ \\
\hline \multicolumn{6}{|l|}{ Market niche } \\
\hline $\begin{array}{l}\text { Our NPO is engaged in a strong competitive battle with other } \\
\text { organisations }\end{array}$ & 177 & $0.203^{* *}$ & 0.007 & 2.42 & 0.82 \\
\hline In our area of activity we are one of the leading organisations & 177 & $0.281 * *$ & 0.000 & 1.82 & 0.91 \\
\hline We invest a great deal in our relationship to our beneficiaries & 177 & $0.252 * *$ & 0.001 & 1.84 & 0.87 \\
\hline In the future we expect an increasing demand for our services & 177 & $0.254 * *$ & 0.001 & 1.95 & 0.82 \\
\hline $\begin{array}{l}\text { We know our market and are aware of what organisations/ } \\
\text { companies work in a manner resembling ours }\end{array}$ & 177 & $0.219^{* *}$ & 0.003 & 1.64 & 0.73 \\
\hline \multicolumn{6}{|l|}{ Innovation } \\
\hline Innovations are accepted positively within the organisation & 177 & $0.298 * *$ & 0.000 & 1.98 & 0.81 \\
\hline $\begin{array}{l}\text { Organisational development is an important theme for the } \\
\text { managerial board/foundation board }\end{array}$ & 177 & $0.292 * *$ & 0.000 & 2.29 & 1.00 \\
\hline Our NPO continually goes through a renewal process & 177 & $0.305^{* *}$ & 0.000 & 2.21 & 0.95 \\
\hline $\begin{array}{l}\text { Innovation impulses originate with the managerial board/ } \\
\text { foundation board }\end{array}$ & 177 & 0.13 & 0.085 & 2.53 & 0.97 \\
\hline Innovation impulses originate wtih the management & 177 & $0.325 * *$ & 0.000 & 1.65 & 0.87 \\
\hline Innovation impulses originate with the staff & 177 & $0.223 * *$ & 0.003 & 2.20 & 0.91 \\
\hline \multicolumn{6}{|l|}{ Coordination } \\
\hline $\begin{array}{l}\text { The decision-making bodies operate on a strictly separate } \\
\text { basis }\end{array}$ & 177 & 0.131 & 0.081 & 1.80 & 1.05 \\
\hline $\begin{array}{l}\text { Managerial board/foundation board is composed mainly on } \\
\text { the basis of expertise }\end{array}$ & 177 & $0.228 * *$ & 0.002 & 1.96 & 0.94 \\
\hline $\begin{array}{l}\text { Managerial board/foundation board is composed mainly on } \\
\text { the basis of the reputation of the members }\end{array}$ & 177 & $0.262 * *$ & 0.000 & 2.41 & 1.01 \\
\hline $\begin{array}{l}\text { Managerial board/foundation board determines the strategy of } \\
\text { the organisation }\end{array}$ & 177 & $0.202 * *$ & 0.007 & 1.61 & 0.91 \\
\hline $\begin{array}{l}\text { Managerial board/foundation board reviews the } \\
\text { implementation of its decisions }\end{array}$ & 177 & $0.259^{* *}$ & 0.001 & 1.63 & 0.77 \\
\hline $\begin{array}{l}\text { Managerial board/foundation board exercises its total } \\
\text { organisational responsibility }\end{array}$ & 177 & $0.193 * *$ & 0.01 & 1.68 & 0.87 \\
\hline $\begin{array}{l}\text { The managerial board mostly agrees on strategic } \\
\text { developments }\end{array}$ & 177 & $0.185^{* *}$ & 0.014 & 1.61 & 0.79 \\
\hline $\begin{array}{l}\text { Decisions made by the managerial board/foundation board are } \\
\text { in general widely accepted in the organisation }\end{array}$ & 177 & $0.249 * *$ & 0.001 & 1.79 & 0.77 \\
\hline $\begin{array}{l}\text { In its decision-making the managerial board is dependent } \\
\text { upon the recommendations of the executive board }\end{array}$ & 177 & $0.202 * *$ & 0.007 & 1.63 & 0.86 \\
\hline $\begin{array}{l}\text { The channels of decision-making are transparent and } \\
\text { comprehensible }\end{array}$ & 177 & 0.139 & 0.065 & 1.64 & 0.76 \\
\hline \multicolumn{6}{|l|}{ Motivation } \\
\hline Our activities have a strategic goal orientation. & 177 & $0.27^{* *}$ & 0.000 & 1.69 & 0.87 \\
\hline $\begin{array}{l}\text { Our NPO has a mission statement and additional management } \\
\text { tools }\end{array}$ & 177 & $0.265^{* *}$ & 0.000 & 1.38 & 0.81 \\
\hline In our NPO there is a unified management concept. & 177 & $0.169 *$ & 0.025 & 1.86 & 0.96 \\
\hline The satisfaction of the full-time staff is generally high & 177 & $0.385 * *$ & 0.000 & 1.72 & 0.74 \\
\hline $\begin{array}{l}\text { The satisfaction of the honorary and voluntary staff is } \\
\text { generally high }\end{array}$ & 177 & $0.284 * *$ & 0.000 & 1.79 & 0.65 \\
\hline
\end{tabular}


Table 7 continued

\begin{tabular}{|c|c|c|c|c|c|}
\hline Items & $N$ & $r$ & $p$ & Mean & $\mathrm{SD}$ \\
\hline $\begin{array}{l}\text { The management has its own high degree of scope for } \\
\text { development }\end{array}$ & 177 & $0.161 *$ & 0.033 & 1.77 & 0.84 \\
\hline \multicolumn{6}{|l|}{ Programme result } \\
\hline $\begin{array}{l}\text { Through our services the majority of the beneficiaries in the } \\
\text { last year experienced a marked improvement }\end{array}$ & 176 & $0.546 * *$ & 0.000 & 1.75 & 0.82 \\
\hline $\begin{array}{l}\text { The number of programmes and services increased in the last } \\
\text { year }\end{array}$ & 176 & $0.570 * *$ & 0.000 & 2.21 & 1.11 \\
\hline The quality of the services was improved in the last year & 176 & $0.801 * *$ & 0.000 & 1.95 & 0.77 \\
\hline $\begin{array}{l}\text { Generally, the beneficiaries are satisfied with the range of } \\
\text { services of our NPO }\end{array}$ & 175 & $0.610 * *$ & 0.0000 & 1.60 & 0.59 \\
\hline $\begin{array}{l}\text { The organisation was altogether very successful in the } \\
\text { achievement of the specified goals }\end{array}$ & 176 & $0.723 * *$ & 0.000 & 1.79 & 0.64 \\
\hline
\end{tabular}

$* p<0.05 ; * * p<0.01$

Table 8 Statistical information on financial excellence

\begin{tabular}{|c|c|c|c|c|c|c|c|c|}
\hline & $N$ & Min & $\operatorname{Max}$ & Mean & SD & $25 \%$ & Median & $75 \%$ \\
\hline $\begin{array}{l}\text { Factor financial } \\
\text { excellence }\end{array}$ & 156 & 0.62 & 2.5 & 1.02 & 0.1465 & 1 & 1 & 1.03 \\
\hline \multicolumn{9}{|c|}{ Financial code according to legal form } \\
\hline \multicolumn{9}{|l|}{ Associations } \\
\hline Profit & 114 & -1500000 & 91000000 & 6140149.31 & 13994489.3 & 624576 & 1750000 & 6357517 \\
\hline Fund-raising yield & 117 & 0 & 21000000 & 1795826.18 & 3510126.65 & 129800.5 & 448879 & 1755276.5 \\
\hline Subvention yield & 108 & 0 & 46871000 & 1883154.99 & 5783833 & 48350 & 354500 & 1400000 \\
\hline $\begin{array}{l}\text { Personal } \\
\text { contribution yield }\end{array}$ & 113 & 0 & 38000000 & 1615401.38 & 5007243.05 & 15054.2 & 150000 & 976500 \\
\hline Surplus & 108 & -1716500 & 686000 & -1535.92926 & 273809.529 & -18983 & 2435 & 48150 \\
\hline \multicolumn{9}{|l|}{ Foundations } \\
\hline Profit & 49 & 0 & 53700000 & 10771097.43 & 12612323.6 & 1822500 & 5834684 & 18000000 \\
\hline Fund-raising yield & 49 & 0 & 27358270 & 3314658.71 & 6456151.48 & 108000 & 500000 & 1731500 \\
\hline Subvention yield & 47 & 0 & 26181990 & 4246166.45 & 6226081.54 & 0 & 1370000 & 5636866 \\
\hline $\begin{array}{l}\text { Personal } \\
\text { contribution yield }\end{array}$ & 45 & -128000 & 18000000 & 3444887.09 & 5408173.29 & 105670 & 1100000 & 2708949.5 \\
\hline Surplus & 46 & -11847000 & 4453220 & -111815.85 & 1993422.79 & -3326 & 4185.5 & 174250 \\
\hline
\end{tabular}

\section{References}

Aberg P, von Essen J (2010) Isomorphic processes and discursive strategies Swedish study associations caught between civil society, the state and the market, In: ISTR Conference Working Papers Vol. 7

Aldrich T (2009) Benchmarking the fundraising performance of UK charities, In: International Journal of Nonprofit and Voluntary Sector Marketing, 14 (4): S353-S364

Anheier HK (2003) Der Dritte Sektor in Zeiten des gesellschaftlichen Umbruchs, In: VerbandsManagement, 28(1): S38-S47

Anheier HK, Leat D (2002) From charity to creativity: philanthropic foundations in the 21st century. Comedia, Stroud 
Anheier HK, Toepler S (2005) Definition und Phänomenologie der Nonprofit-Organisation. In: Hopt KJ, von Hippel Th, Walz WR (eds) Nonprofit-Organisationen in Recht, Wirtschaft und Gesellschaft, Tübingen, pp S17-S34

Anheier HK, Schröer A, Then V (eds) (2011) Soziale Investitionen. VS Verlag, Wiesbaden

Badelt Ch, Meyer M, Simsa R (2007) Handbuch der Nonprofit-Organisation, 4th edn. Schäffer-Poeschel, Stuttgart

Balser D, McClusky J (2005) Managing stakeholder relationships and non-profit organization effectiveness, In: Nonprofit Management and Leadership, 15(3): S295-S315

Baruch Y, Ramalho N (2006) Communalities and distinctions in the measurement of organizational performance and effectiveness across for-profit and non-profit sectors, In: Nonprofit and Voluntary Sector Quarterly, 35(1): S39-S65

Boezeman EJ, Ellemers N (2008) Volunteer recruitment: the role of organizational support and anticipated respect in non-volunteers' attraction to charitable volunteer organizations. J Appl Psychol 93(5):S1013-S1026

Bowman HW (2006) Should donors care about overhead? Do they care? Nonprofit Volunt Sect Q 35(2):S288-S310

Brown AW (2005) Exploring the association between board and organizational performance in non-profit organizations, In: Nonprofit Management and Leadership, 15(3): S317-S339

Brown AW, Yoshioka C (2002) Employee satisfaction and mission attachment as factors in retention. Paper presented at the Association for Research on Nonprofit Organizations and Voluntary Action, Montreal

Bruhn M (2005) Marketing für nonprofit-organisationen. Grundlagen - Konzepte - Instrumente, Kohlhammer

Bryson JM, Gibbons MJ, Shaye G (2001) Entreprise schemes for nonprofit survival, growth, and effectiveness, In: Nonprofit Management and Leadership, 11(3): S271-S288

Callen JL, Klein A, Tinkelman D (2003) Board composition, committees, and organizational efficiency: the case of nonprofits, In: Nonprofit and Voluntary Sector Quarterly, 32(4): S493-S520

Chew C (2005) Strategic marketing planning and positioning in voluntary non-profit organisations. Aston Academy for research in Management, Aston

Cornforth Ch (2003) The governance of public and non-profit organisations: what do boards do?. Routledge, London

Cornforth Ch, Simpson C (2003) Change and continuity in the governance of non-profit organizations in the UK, In: Nonprofit Management and Leadership, 12(4): S451-S470

DiMaggio P, Powell WW (1983) The iron cage revisited: institutional isomorphism and collective rationality in organizational fields, In: American Sociological Review, 48(4): S147-S160

Eikenberry AM, Kluver JD (2004) The marketization of the non-profit sector: civil society at risk? In: Public Administration Review, 64(2): S132-S140

Ergenzinger R, Krulis-Randa JS (2005) Innovation als Erfolgsfaktor des professionellen Management in der postindustriellen Organisation. In: Berndt R (ed) Erfolgsfaktor Innovation. Springer Verlag, Heidelberg, pp 97-111

Forbes DP (1998) Measuring the unmeasurable: empirical studies of non-profit organization effectiveness from 1977 to 1997, In: Nonprofit and Voluntary Sector Quarterly, 27(2): S183-S202

Frey BS, Benz M (2007) Corporate Governance: what Can We Learn From Public Governance? Acad Manag Rev 32(1):92-104

Gill M, Flynn RJ, Reissing E (2005) The governance self assessment checklist, In: Nonprofit Management and Leadership 15(3): S271-S294

Strachwitz R Graf (2010) Stiften, Philanthropie und Venture Philanthropy, In: Hoelscher Ph, Ebermann Th, Schlüter A (Hrsg.) Venture Philanthropy in Theorie und Praxis, Lucius \& Lucius, Stuttgart, S49-S56

Green JC, Griesinger DW (2006) Board performance and organizational effectiveness in non-profit social services organizations, In: Nonprofit Management and Leadership, 6(4): S381-S402

Greiling D (2009) Erfolgsmassstäbe für Nonprofit-Organisationen, In: Betriebswirtschaftliche Forschung und Praxis, 61(1): S56-S78

Hair JF, Anderson RE, Tatham RE, Black WC (2006) Multi-variate data analysis, 6th edn. Pearson/ Prentice Hall, Upper Saddle River

Harris M (1998) Doing it their way: organizational challenges for voluntary associations, In: Nonprofit and Voluntary Sector Quarterly, 27(2): S144-S158 
Helmig B, Jegers M, Laspley I (2004) Challenges in managing non-profit organizations: a research overview. Voluntas 15(2):101-116

Helmig B, Purtschert R, Beccarelli C (2006) Erfolgsfaktoren im nonprofit-management. In: Helmig B, Purtschert R (eds) Nonprofit-management, 2nd edn. Gabler, Wiesbaden, pp 351-360

Helmig B, Lichtsteiner H, Gmür M (2010) Der Dritte Sektor der Schweiz. Haupt, Benr

Herman RD, Renz DO (2008) Advancing non-profit organizational effectiveness research and theory, In: Nonprofit Management and Leadership, 18(4): S399-S415

Herman RD, Renz DO, Heimovics RD (1997) Board practices and board effectiveness in local non-profit organizations, In: Nonprofit Management and Leadership, 7(4): S373-S285

Hirschman AO (1987) Exit, voice, and loyalty. Harvard University Press, Cambridge

Jakob D, Huber R, Rauber K (2009) Non-profit law in Switzerland, working papers of the Johns Hopkins comparative non-profit sector project, No. 47, The Johns Hopkins Center for Civil Society Studies, Baltimore

Jaskyte K (2004) Transformational leadership, organizational culture, and innovativeness in non-profit organizations, In: Nonprofit Management and Leadership, 15(2): S153-S168

Jaskyte K, de Riobo MS (2004) Characteristics of innovative non-profit organizations in Argentina. Voluntas 15(1):71-79

Kaiser HF (1974) An index of factorial simplicity. Psychometrika 39:31-36

Maier F, Meyer M (2011) Managerialism and beyond: discourses of civil society organization and their governance implications. Voluntas 22(4):731-756

Mazzarol TW, Soutar GN (2007) Strategy matters: strategic positioning and performance in the education services sector, In: International Journal of Nonprofit and Voluntary Sector Marketing, 13(2): S141S151

Meyer M (2008) Paradoxien im nonprofit sektor, In: Verbands-Management, 34(1): S6-S15

Meyer JW, Rowan B (1977) Institutional organizations: formal structure as myth and ceremony. Amer J Sociol 83:340-363

Murray V, Bradshaw P, Wolpin J (1992) Power in and around non-profit boards: a neglected dimension of governance, In: Nonprofit Management and Leadership, 3(2): S165-S182

Nowotny Ch, Fida S (2007) Rechtliche Gestaltungsformen für NPOs. In: Badelt Ch, Meyer M, Simsa R (eds) Handbuch der Nonprofit-organisation, 4th edn. Schäffer-Poeschel, Stuttgart, pp 202-230

Nunnally JC (1978) Psychometric theory, 2nd edn. MacGraw-Hill, New York

Osborne SP (1998) Voluntary organizations and innovation in public services. Routledge, London

Parsons E, Broadbridge A (2004) Managing change in non-profit organizations: insights from the UK charity retail sector. Voluntas 15(3):227-242

Peter JP (1979) Reliability: a review of psychometric basics and recent marketing practices. J Mark Res 16:S6-S24

Porter M (1985) Competitive advantage. Free Press, New York

Purtschert R (2004) Good corporate governance: Ansatz für Verbände und weitere NPO? In: VerbandsManagement, 30(3): S6-S17

Purtschert R (2005) Marketing für Verbände und weitere Nonprofit-Organisationen, 2nd edn. Haupt, Bern

Robinson JP, Shaver PR, Wrightsman LS (1991) Measures of personality and social psychological attitudes. Academic Press, San Diego

Sargeant A (2001) Relationship Fundraising: how to keep your donors loyal, In: Nonprofit Management and Leadership, 12(2): S177-S192

Schönenberg D (2009) Transformation vom Verein in eine Stiftung im Schweizer Recht, In: Zeitschrift für das Recht der Non Profit Organisationen, Heft 3/2009, S64-S67

Schwarz P (1984) Erfolgsorientiertes Verbands-Management. Asgard, St. Augustin

Schwarz P (1996) Management in nonprofit organisationen. Haupt, Bern

Schwarz P (2003) Erfolgsorientierung in Nonprofit-Organisationen: Zur Konstruktion eines Modells. In: Blümle E-B, Pernsteiner H, Purtschert R, Andessner R (eds) Öffentliche Verwaltung und NonprofitOrganisationen. Linde, Wien, pp 641-662

Schwarz P (2005) Organisation von Nonprofit-Organisationen. Haupt, Bern

Schwarz P (2006) Management-Prozesse und -Systeme in Noprofit-Organisationen. Haupt, Bern

Schwarz P, Lichtsteiner H (2008) Management professionalisierung in NPO: Ein Irrweg? In: VerbandsManagement, 34(1): S16-S25

Schwarz P, von Schnurbein G (2005) Gemeinsamkeiten und strukturelle Unterschiede der Corporate und Nonprofit Governance, In: Zeitschrift für öffentliche und gemeinwirtschaftliche Unternehmen, 28(4): S358-S375 
Schwarz P, Purtschert R, Giroud Ch, Schauer R (2009) das Freiburger Management-Modell für Nonprofit-Organisationen, 6th edn. Haupt, Bern

Seufert G (1999) Verbandscontrolling: Ansätze einer operativen Führungskoordination. Gabler, Wiesbaden

Siciliano JI (1997) The relationship between formal planning and performance in non-profit organizations, In: Nonprofit Management and Leadership, 7(4): S387-S403

Steyerer J, Meyer M (2010) Welcher Führungsstil führt zum Erfolg? In: Zeitschrift Führung und Organisation, 79(3): S148-S155

Toepler S, Feldman M P (2003) Philanthropic foundations and the innovative function: evidence from a survey of university researchers, mimeo, George Mason University

Tschirhart M (2006) Non-profit membership associations. In: Powell WW, Steinberg R (eds) The nonprofit sector - a research handbook, 2nd edn. Yale University, New Haven, pp 523-541

Van de Ven AH (1986) Central problems in the management of innovation. Manag Sci 32:509-607

Verbruggen S, Christiaens J, Milis K (2011) Can resource dependence and coercive isomorphism explain non-profit organizations' compliance with reporting standards? In: Nonprofit and Voluntary Sector Quarterly, 40(1): S5-S32

von Schnurbein G (2007) Risiko- und innovationsorientierte Förderleistungen von Stiftungen, In: Helmig B, Purtschert R, Schauer R, Witt D (2007) Nonprofit-Organisationen und Märkte, DUV, Wiesbaden, pp S323-S338

von Schnurbein G (2008) Stiftungen als Motor des Wandels im Nonprofit-Sektor, In: Zeitschrift zum Stiftungswesen

von Schnurbein G (2009) Patterns of governance in swiss trade Associations and unions, In: Nonprofit Management and Leadership, 20(1): S97-S115

von Schnurbein G (2010) Dienstleistungsorientiertes Stiftungsmanagement, In: Rote Seiten, Nr.5/2010, S2-S13

von Schnurbein G, Timmer K (2010) Die Förderstiftung. Helbing Lichtenhahn, Basel

Wollebaek D (2009) Survival in local voluntary associations, In: Non-profit Management and Leadership, 19(3): S267-S284

Young DR (2004) The music of management—applying organization theory. Ashgate, Burlington 